\title{
Death, Relics, and the Demise of Huts: Patterns of Planned Abandonment in Middle BA Central Iberia
}

\author{
Alejandra Sánchez-Polo ${ }^{1}$ and Antonio Blanco-González ${ }^{2}$ \\ ${ }^{1}$ Departamento de Prebistoria, Ha Antigua y Arqueología, Universidad de Salamanca, \\ Spain \\ ${ }^{2}$ Department of Archaeology, Durham University, $U K$
}

This paper addresses the formation processes at an unparalleled Bronze Age settlement in the Iberian Meseta. The site of El Cerro (Burgos, Spain) presents a series of challenging features: the simultaneous inhumation of three subadults alongside a dwelling quarter and adjacent pits, some of them filled with apparent formality, including such anachronistic elements as Neolithic and Beaker items and several placed deposits, such as a leg of a cow. A critical evaluation of the contextual dataset, a re-fitting operation, and an assessment of the abrasion and size of a ceramic sample were carried out. The archaeological peculiarities of the site are explained as a contextually specific cultural response to a grievous and traumatic episode: the death of three young siblings, which entailed the abandonment of the settlement through prescribed practices. Some depositions are a product of recognizable intentionality, while others are regarded as unintended cumulative outcomes.

Keywords: Middle Bronze Age, Iberia, deposition, site formation processes, deviant burial, pottery, abrasion, fragmentation

\section{INTRODUCTION}

Later prehistoric evidence in central Iberia shares with many western European regions its inconsistent and ambiguous nature (Brück, 1999b; Gerritsen, 1999; Lamdin-Whymark, 2008; Garrow, 2012). Bronze Age remains appear too often in secondary contexts (for example, Abarquero et al., 2013), and the more ubiquitous archaeological features-those dug in the subsoil such as frequent pits and rare hut floors-have normally been subjected to post-abandonment disturbance. However, post-depositional processes cannot be considered the only or the major factors responsible for this widespread image. In the Iberian Meseta, we now think (Sánchez-Polo, 2010; BlancoGonzález, 2011) that the causes for this lack of reliable depositional contexts are partly connected with the particular forms of abandonment practiced by Bronze Age people, which entailed systematic recycling and removal of their remains.

This paper addresses such a pitfall by focusing on an outstanding case study: a Bronze Age residential site that arguably came to an end in extraordinary circumstances. On the occasion of the death of 
three kin-related children, some quite particular cultural practices could have been performed by its inhabitants to sanction the completion of its last occupation. This interpretive proposal has been reached through a critical reappraisal of the contextual data obtained in the rescue excavation at this site in 1996 (Negredo \& Palomino, 1997; Palomino et al., 1999). This hypothesis also draws upon the practical examination of the fragmentation and abrasion of a sample of the ceramic material recovered in the mid-1990s. These tasks have been successful in recognizing different patterns of deposition, some of them absent in most known contemporary sites. In particular, we can identify a substantial quantity of anachronistic Neolithic items and a handful of Beaker sherds introduced into the Bronze Age negative features, which appear to be placed depositions. All in all, these data offer vital clues to discuss a range of depositional histories identified at El Cerro, although this should not eclipse their full interpretive potential (Brudenell $\&$ Cooper, 2008).

\section{El Cerro Site}

El Cerro is located in the municipality of La Horra (Burgos, Spain), in the central area of the Northern Meseta, a sedimentary area of flat lowlands (Figure 1). The site lies on the summit of a smooth-sided hill between the El Prado and Madre seasonal streams, surrounded by very fertile fields close to the basin of the major river in the region, the Duero (Figure 1). Its archaeological nature was acknowledged in 1996 on the occasion of large-scale ground disturbance by a bulldozer in order to build wine cellars. This work allowed the recognition of several negative or cut features with dark fill in the wide exposed section, and prompted developer-funded archaeological excavations.

A total of $550 \mathrm{~m}^{2}$ was excavated in an open area, yielding thirty-two features, four of which were dated to the Early Medieval period, dug into the sandy geological substratum (Negredo \& Palomino, 1997; Palomino et al., 1999). Only one later prehistoric cultural phase was identified, corresponding to the earlier stage of the Cogotas I culture in the Middle Bronze Age (1800-1450 cal BC) (Abarquero et al., 2013). More specifically, the unearthed features can be described as pits or shallow hollows with varied sections and dimensions, ranging from 0.60 to $2.5 \mathrm{~m}$ wide at their top and between 0.2 and $1 \mathrm{~m}$ deep. They were filled with anthropogenic black ashy deposits and variable proportions of domestic remains such as lumps of fired daub, lithic debris, potsherds, and faunal remains. The sediments inside some pits were occasionally stratified, but no stratigraphic relationships were identified between different features.

Several hollows were initially thought to be the possible sunken floors of huts (Palomino et al., 1999), but only Feature (F.) 23 is likely to have been so (Figure 2). It is worth noting that living quarters have only occasionally been documented during the first half of the second millennium $\mathrm{BC}$ in central Iberia. They were invariably made of perishable materials (wattle-and-daub) and were very often semi-sunken features dug into the bedrock (Sánchez-Polo, 2010: 178-81; BlancoGonzález, 2011: 394-99). This site can arguably be interpreted as a semipermanent settlement: the outcome of several discontinuous reoccupations lasting for an ill-defined timespan. This model of short-lived sites, used by small and unstable agrarian communities according to a 'wandering' settlement pattern (Gerritsen, 1999) matches the main lines of currently available data (Palomino et al., 


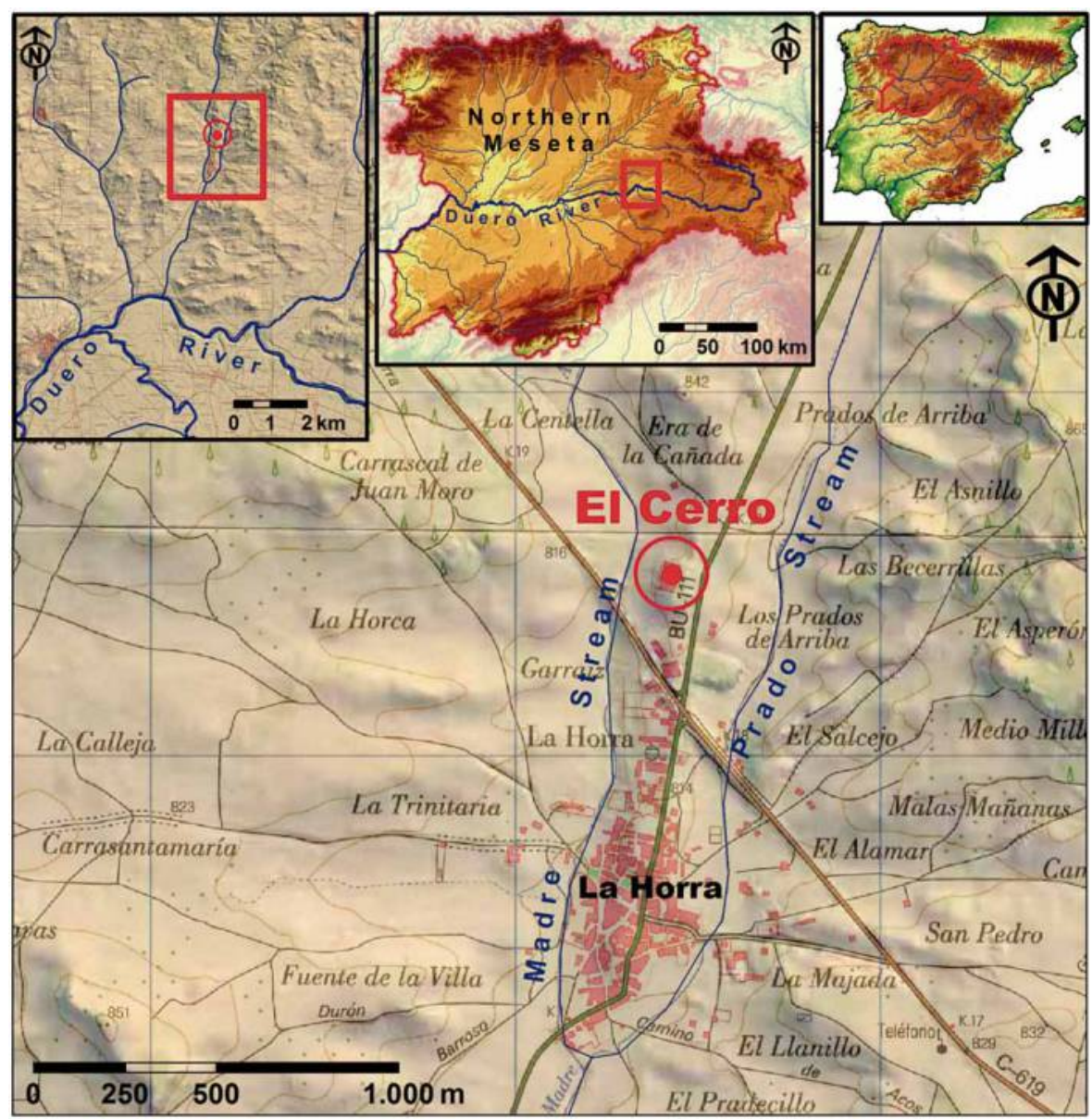

Figure 1. The El Cerro site in the Northern Meseta in central Iberia near the Duero River, including a detailed map of its location on the outskirts of La Horra village (Burgos, Spain).

1999; Blanco-González, 2011; Abarquero et al., 2013).

F. 23 is $4.3 \mathrm{~m}$ long by $3.9 \mathrm{~m}$ wide and $0.4 \mathrm{~m}$ deep, and it was delimited to the west by two postholes that suggest the inclusion of pit F. 22 within this building as a probable ground storage silo (Palomino et al., 1999: 24) (Figure 3D). No trace of its original superstructure has survived. This hollow was filled by homogeneous grey sandy and loose sediment, with frequent charcoal particles, small fired daub fragments, faunal remains, flint flakes, and 209 sherds, many of them exhibiting typical Middle Bronze Age decoration (Figure 4). The decorated fineware in this style consists of hemispheric bowls, plates, and open carinated bowls featuring incised or impressed geometric motifs such as grids, zigzags, triangles, and herringbone patterns arranged in bands (Blasco et al., 2007: 108-13; Rodríguez Marcos, 2007: 315-30; Abarquero et al., 2013: 315-16). F. 23 also yielded two very characteristic impressed Early Neolithic potsherds (Figure 5, B2 and B3), one of them featuring a 'stab-and-drag' motif (Figure 5, B3) (Estremera, 2003) whose decorations cannot be mistaken with Middle Bronze Age ornaments. 


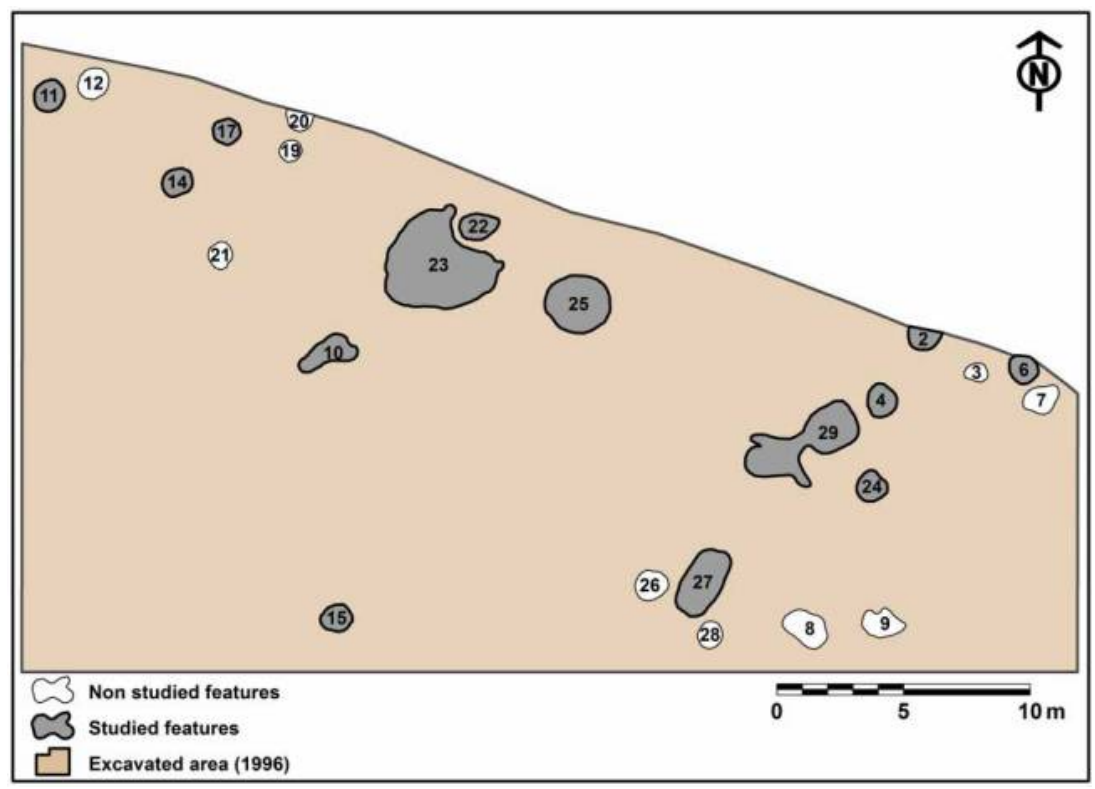

Figure 2. Simple plan of the archaeological features discovered in 1996 at El Cerro. After Negredo \& Palomino (1997).

Only $3 \mathrm{~m}$ away from F. 23 was hollow F. 10 ( $2.3 \mathrm{~m}$ long and $1.08 \mathrm{~m}$ wide), which contained the skeletal remains of three subadults (Figure 2). Recent radiocarbon determinations, complete with bioarchaeological, isotopic, and aDNA studies on these human remains (Esparza et al., 2012a), has shed new light on the circumstances of their burial. ${ }^{1}$ The skeleton nearest to the surface was badly affected by intense post-depositional truncation. It belongs to an adolescent boythe sex was determined by aDNAaround twelve to fourteen years old, whose body was orientated on a northsouth axis with his head towards the south, and his arms and legs tightly flexed (Figure 3A). Below this inhumation, and separated by a thin layer of $10-15 \mathrm{~cm}$ of the same sediment filling the whole

\footnotetext{
${ }^{1}$ These studies have been undertaken within the ongoing research project HAR 2009-10105 led by Prof. Ángel Esparza (University of Salamanca), which focuses on Bronze Age human remains in central Iberia (Spain).
}

hollow F. 10, two complete subadult male and female skeletons were found (Figure 3B). These two children, between four and nine years old, were placed with the same orientation as the superimposed boy and their bodies were intertwined, face to face, one lying on its left side, the other on the opposite side (Palomino et al., 1999: 25-27). One direct AMS date was obtained from each individual interred in F. 10 (A. Esparza, personal communication, 2013) — these are the only radiocarbon determinations available from this site. ${ }^{2}$ The uppermost boy is dated to 1600-1430 cal BC (Poz-16556, $3225 \pm$ $30 \mathrm{BP})$, whereas the underlying girl (Poz-16514, $3180 \pm 50 \mathrm{BP})$ and the small boy $(\mathrm{Poz}-16604,3210 \pm 35$ BP) were dated to $1600-1320 \mathrm{cal} \mathrm{BC}$ and $1605-$ 1410 cal BC, respectively. Thus, based on

\footnotetext{
${ }^{2}$ All the radiocarbon dates, which are presented here for the first time, have been calibrated using Oxcal 4.2 using the Intcal09 curve (Reimer et al., 2009) and are expressed at 2 -sigma range.
} 

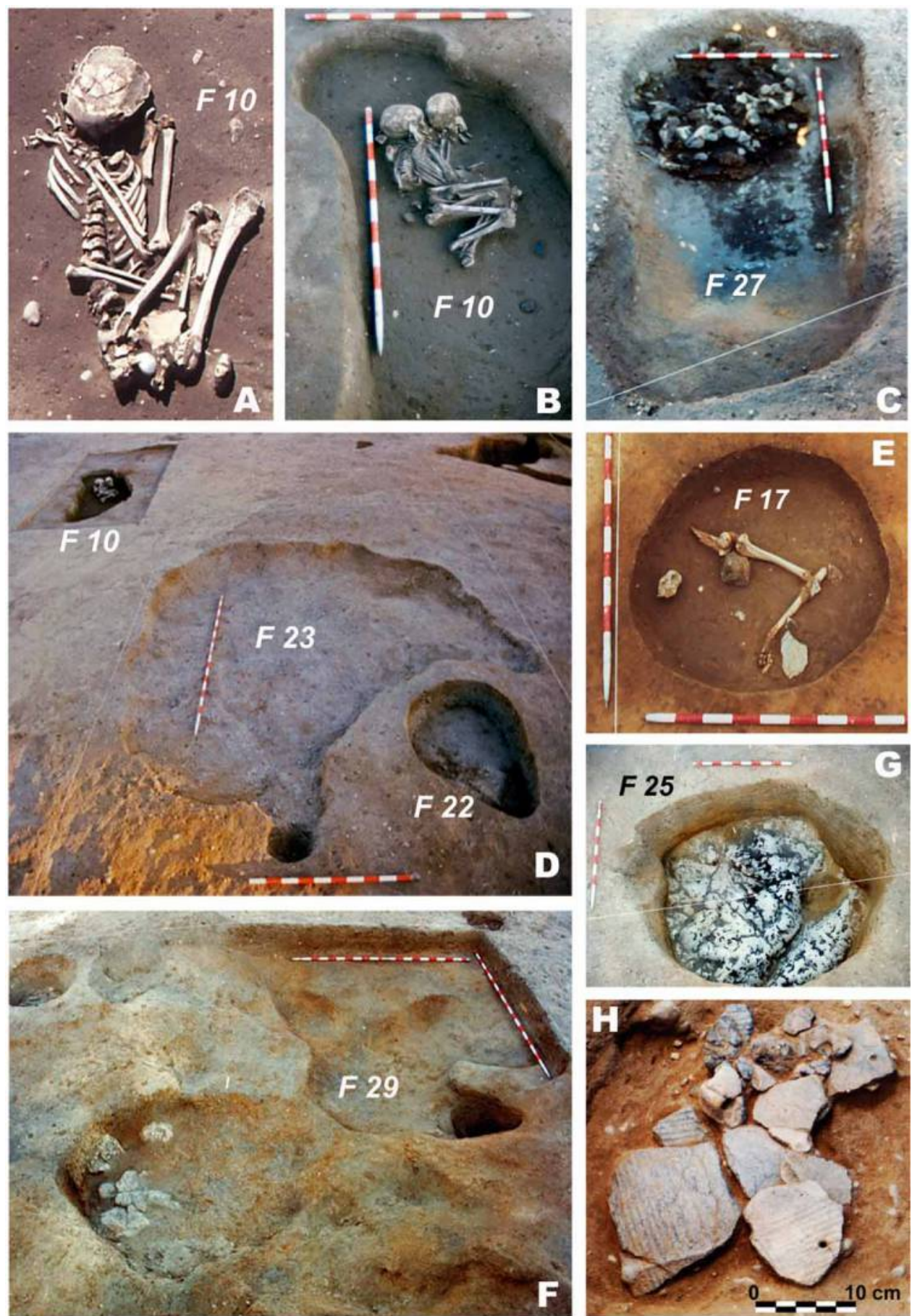

Figure 3. (A) Uppermost individual in F. 10. (B) The deepest two subadults in F. 10. (C) In the background, the ruined kiln or oven of F. 27. (D) Hut F. 23 and its surrounding pits. (E) Pit F. 17 which contained an articulated cow's leg. (F) Gully F. 29. (G) Remnants of a bonfire deposited in pit F. 25. (H) Neolithic grooved sherds cached in situ within SU 2901.

Photographs: A.L. Palomino. 


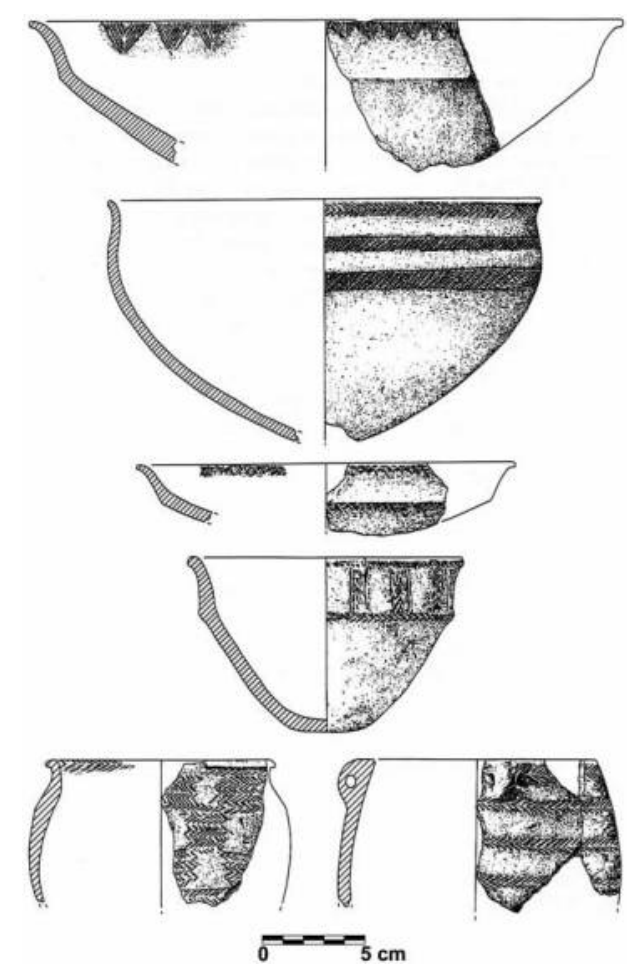

Figure 4. Middle Bronze Age decorated pottery from $\mathrm{El}$ Cerro.

After Palomino et al. (1999: 30, fig. 7).

their almost simultaneous calibrated radiocarbon intervals, the absence of sedimentary hiatus and their shared orientation it is possible to exclude the possibility of a long-lasting depositional sequence. All the evidence points towards a unique and triple burial episode. In other words, all of the bodies were most likely interred together within a short timespan. Importantly, the preliminary aDNA results (A. Esparza, personal communication, 2013) ${ }^{3}$ indicate that at least

\footnotetext{
${ }^{3}$ The analyses of nuclear and mitochondrial aDNA have been conducted in the Ancient DNA Laboratory by the Research Group on Forensic Genetics and Population Genetics (Faculty of Medicine, Complutense University of Madrid). These initial results are pending the completion of a second sampling test in a different laboratory, but they yielded a relatively high value of siblingship between the uppermost adolescent and the subadult male which corresponds to $W=94.78 \%$.
}

two of them-the uppermost and one of the deepest, as the other one lacks genetic matter-were most likely siblings (Esparza et al., 2012a: 279-81, 306-07). The other cultural materials recovered from F. 10 were quite abundant, including ninetynine sherds-twenty-eight of them decorated with Bronze Age incised motifs-, siliceous and quartzite debitage debris, sandstone lumps and some bone debris from small animals, yet no grave goods or offerings could be clearly recognized.

The shallow pit F. 17 lacked any significant artefactual material (Table 1); however, it contained an articulated leg of a cow (Figures 2 and 3E). In the shallow pit F. 15, only three fragments of quartzite handstones appeared at its base. Pit F. 24 contained a tiny rock crystal blade, quite unusual in Bronze Age contexts (Figure 5, A1) and one large incised Beaker sherd (Figure 5, C2), assigned to the incised Silos-style, which usually appears on coarse ware (Rodríguez Marcos, 2007: 256-62) as is the case here. Pit F. 25 (Figures 2 and 3G) contained eighty-four sherds and occasional animal bone debris in a fill stratified into three levels, with the deepest (SU 2503) identified as a thick level of ashes and charcoal. The contents of this pit have been interpreted as the remnants of a bonfire lit in another place, which might eventually have been deposited here (Palomino et al., 1999: 2324). F. 25 also contained a microlith segment (Figure 5, A3) of undeniable Neolithic origin, as this kind of lithic production was abandoned before the third millennium BC (for example, Blasco et al., 2007: 129-36; Rodríguez Marcos, 2007: 390). Pit F. 27 (Figures 2 and 3C) is also directly related with fire- a few pieces of lithic debris were burnt-and might have comprised part of a ruined kiln or oven. Its uppermost level (SU 2701) consisted of a pile of sandstone boulders, and a large accumulation of mud, forming a circle 

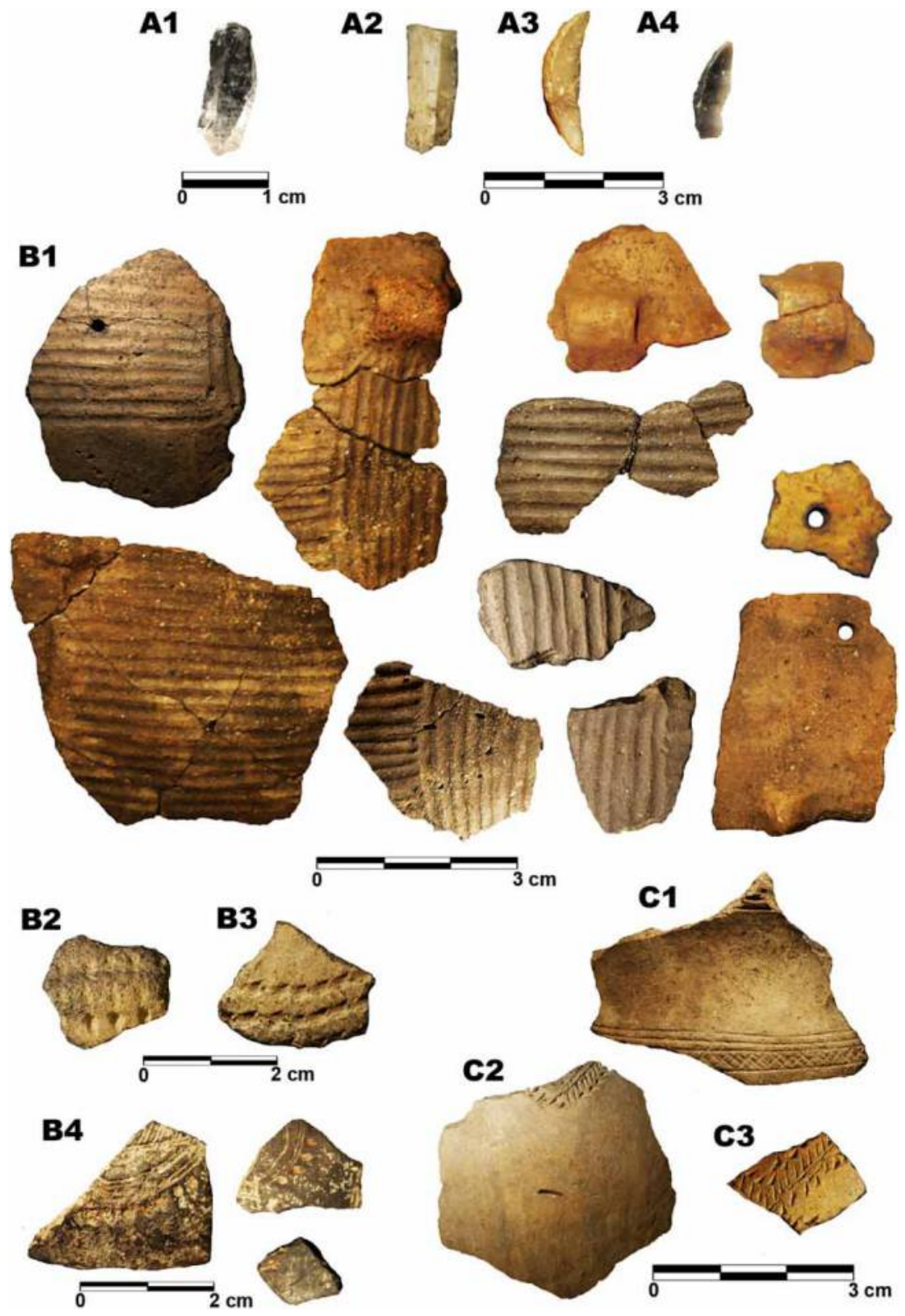

Figure 5. Extemporaneous items in Bronze Age contexts. (A) Lithics: crystal rock blade from $F .24$ (A1), flint blade from F. 27 (A2), flint segment from F. 25 (A3) and microlith from F. 29 (A4). (B) Neolithic sherds: grooved ware from F. 29 (B1), impressed (B2) and 'stab-and-drag' (B3) sherds from $F$. 23, and sherds from F. 6 (B4). (C) Beaker sherds from the surface (C1), from F. 24 (C2) and from F. 27 (C3).

$1.2 \mathrm{~m}$ in diameter and $15-25 \mathrm{~cm}$ thick. A small Beaker sherd, which also exhibits Silos-style decoration (Figure 5, C3) was recovered. In fact its decoration is so close to the sherd from pit F. 24, found some $6 \mathrm{~m}$ away (Figure $7 \mathrm{~B}$ ), that they might 
Table 1. Pottery assemblages per stratigraphic unit (SU) at El Cerro.

\begin{tabular}{lrrrrrrrrr}
\hline Feature & SU & $\begin{array}{c}\text { Total } \\
\text { sherds }\end{array}$ & $\begin{array}{c}\text { Studied } \\
\text { sherds }\end{array}$ & $\begin{array}{c}\text { Weight } \\
\text { (g) }\end{array}$ & $\begin{array}{c}\text { \% Studied } \\
\text { sherds }\end{array}$ & $\begin{array}{c}\text { Min. } \\
\text { no. } \\
\text { vessels }\end{array}$ & $\begin{array}{c}\text { \% Small } \\
(<\mathbf{4} \mathbf{~ c m})\end{array}$ & $\begin{array}{c}\text { \% Medium } \\
(\mathbf{4 - 8} \mathbf{~ c m})\end{array}$ & $\begin{array}{c}\text { \% Large } \\
(>\mathbf{8} \mathbf{~ c m})\end{array}$ \\
\hline F. 2 & 201 & 13 & 5 & 2019 & 38 & 2 & 40 & 0 & 60 \\
F. 4 & 401 & 35 & 11 & 282 & 31 & 11 & 45 & 45 & 10 \\
F. 6 & 601 & 15 & 5 & 126 & 33 & 3 & 40 & 40 & 20 \\
F. 10 & 1004 & 99 & 28 & 349 & 28 & 22 & 71 & 25 & 3 \\
F. 10 & 1005 & 110 & 31 & 954 & 28 & 31 & 42 & 45 & 13 \\
F. 11 & 1101 & 5 & 1 & 736 & 20 & 1 & 0 & 0 & 100 \\
F. 14 & 1401 & 39 & 7 & 170 & 18 & 6 & 57 & 29 & 14 \\
F. 15 & 1501 & 1 & 0 & 0 & 0 & 0 & 0 & 0 & 0 \\
F. 17 & 1701 & 14 & 3 & 321 & 21 & 3 & 0 & 34 & 66 \\
F. 22 & 2201 & 92 & 14 & 474 & 15 & 13 & 43 & 43 & 14 \\
F. 23 & 2301 & 209 & 53 & 1377 & 25 & 53 & 49 & 40 & 11 \\
F. 24 & 2401 & 23 & 2 & 454 & 9 & 2 & 0 & 50 & 50 \\
F. 25 & 2501 & 18 & 3 & 76 & 17 & 3 & 34 & 66 & 0 \\
F. 25 & 2502 & 61 & 12 & 1437 & 20 & 12 & 67 & 33 & 0 \\
F. 25 & 2503 & 5 & 1 & 3 & 20 & 1 & 100 & 0 & 0 \\
F. 27 & 2701 & 141 & 19 & 184 & 13 & 18 & 74 & 26 & 0 \\
F. 29 & 2901 & 307 & 61 & 4323 & 20 & 49 & 43 & 43 & 15 \\
F. 29 & 2902 & 232 & 46 & 5162 & 20 & 45 & 52 & 30 & 17 \\
F. 29 & 2903 & 22 & 10 & 193 & 45 & 10 & 90 & 0 & 10 \\
\hline
\end{tabular}

Key: Total number of recorded ceramic fragments (total sherds); number of studied sherds (studied sherds); weight of studied sherds (weight); percentage of total sherds that were studied (\% studied sherds); minimum number of vessels from the studied sherds (min. No. Vessels) and percentages of sherds according to their size.

have belonged to the same vessel (Palomino et al., 1999: 32). On the other hand, a large Beaker Ciempozuelos-style incised sherd was found on the surface, probably moved from its archaeological context by the plough (Figure 5, C1).

Feature 29 (Figures 2 and 3F) was initially interpreted as a sunken hut with an elongated floor plan, measuring $4 \mathrm{~m}$ by $1.6 \mathrm{~m}$ and $0.4 \mathrm{~m}$ deep, featuring two postholes in the middle of its uneven floor (Palomino et al., 1999: 25). Its fill contained several remarkable features. Three different strata were recognized, in which a total of 561 sherds were found. The deepest one (SU 2903) yielded very scarce archaeological materials (Table 1), among them one flint microlith (Figure 5, A4). The intermediate layer (SU 2902) yielded a large amount of faunal debris and 232 potsherds, some of them belonging to almost complete small hemispheric bowls, probably for individual consumption because of their form, size, and abundance. The uppermost level (SU 2901) was the richest layer in terms of ceramics with 307 potsherds, many of them with typical incised Bronze Age motifs, including the remains of some fine bowls. Remarkably, within this level was also found a small thick-walled jug lacking symmetry and technical skill, interpreted by its excavators (Palomino et al., 1999: 30, fig. 7 n.5) as a child's toy (Figure 6). 


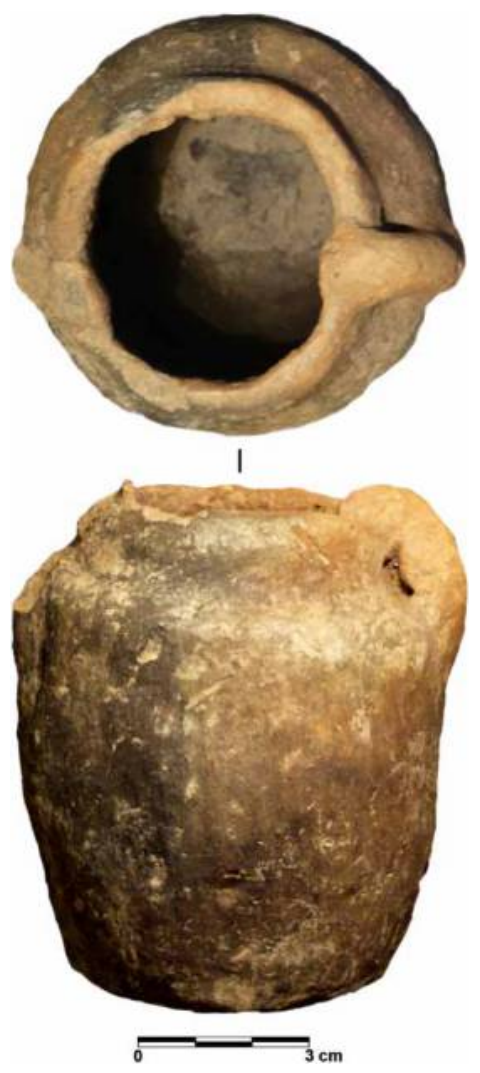

Figure 6. Bronze Age thick-walled jug from the upper layer (SU 2901) within F. 29.

Finally, fifteen grooved sherds which can plausibly be attributed to the Early Neolithic (Figure 5, B1) were found as a cache piled in a discrete point within this upper layer (Figure 3H). These sherds are quite large, their fractures and surfaces are strikingly fresh, and they are probably from the same vessel: some of them even refit. Importantly, all these 'old' materials, recovered at different levels within F. 29 appeared within layers containing Middle Bronze Age material. Finally, close to F. 29 was pit F. 6 (Figure 7A), where three sherds from the same fine vessel featuring incised motifs with red pigmentslikely Early Neolithic decorations because of their stylistic parallels-were recovered (Figure 5, B4).

\section{Assessing the Ceramic Assemblage from El Cerro}

The recognition of 'structured', placed or 'odd' depositions in later prehistoric contexts has improved over the last two decades, mainly in British archaeology (for example, Hill, 1995; Brück, 1999b; Pollard, 2002). However, several successful strands of enquiry have recently raised important caveats against somewhat traditional, over-simplistic and functional interpretations among the studies dealing with these intentional deposits. It is currently agreed that not only extraordinary and more conspicuous depositions, resulting, for example, from deliberate ceremonial or ritualized actions, but also routine and poorly defined deposits-the unintended by-products of everyday practices - should be equally addressed (Brudenell \& Cooper, 2008; LamdinWhymark, 2008; Garrow, 2012). The necessity of properly discerning the complexities of any formative processes to avoid limiting their interpretative potential has been highlighted. Any aprioristic preconceptions should be rejected and replaced with exhaustive analytical approaches based on flexible and representative criteria (Brudenell \& Cooper, 2008). Several recent studies have examined in detail whole assemblages of later prehistoric settlement remains in order to better understand the particular ways prehistoric peoples managed and disposed of their material culture. Thus, reliable insights on different depositional histories in diverse prehistoric contexts have been gained (Garrow et al., 2005; Brudenell \& Cooper, 2008; Edwards, 2009).

Drawing on these thought-provoking proposals, our main goal has been to attain a contextually specific and nuanced reading of the evidence from El Cerro. As illustrated in the previous section, this site can be envisaged as a highly suitable case 

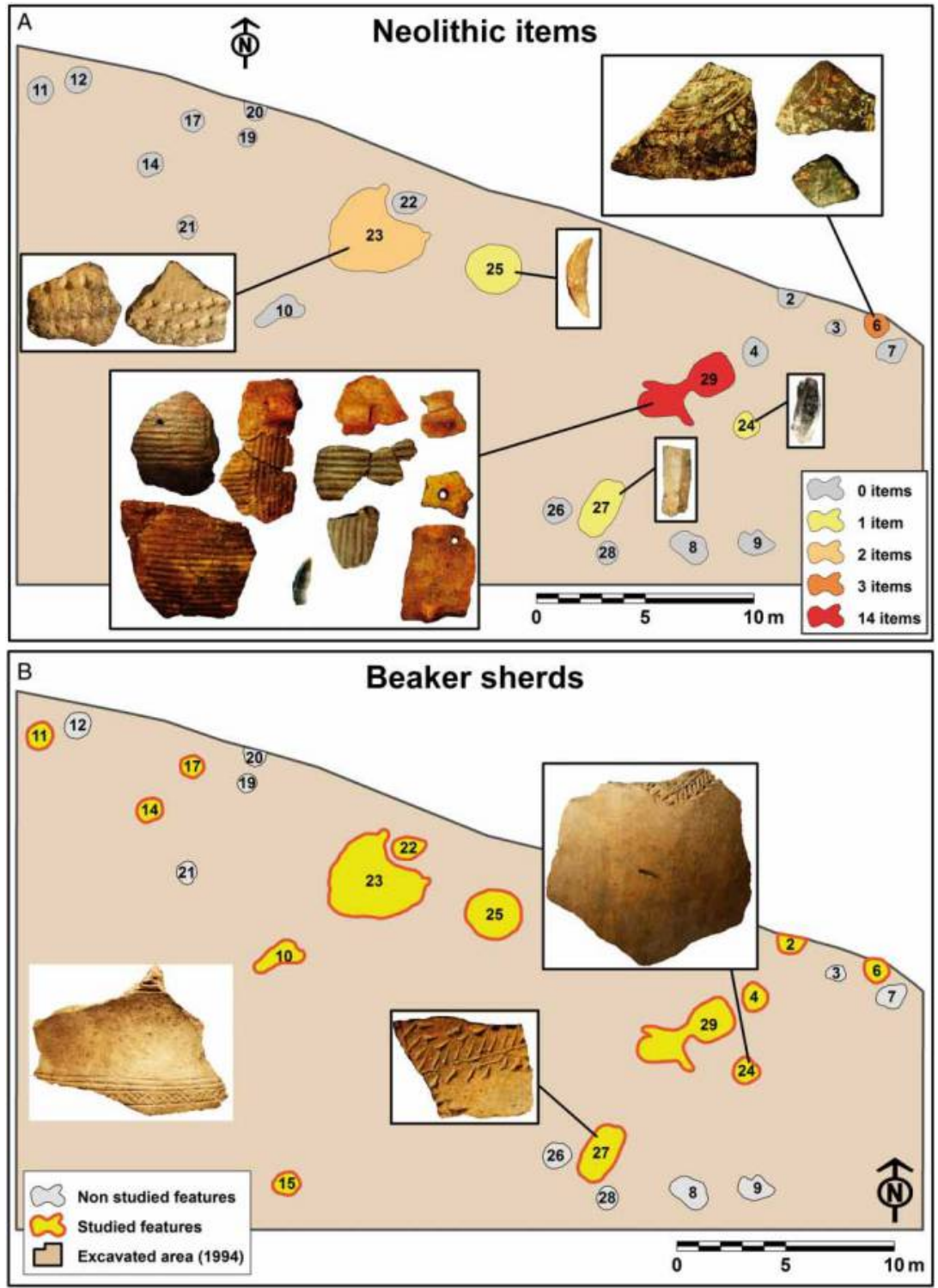

Figure 7. Neolithic and Beaker items at El Cerro. (A) Early Neolithic lithics and sherds. (B) Beaker sherds.

for such a strategy of enquiry, as it consists of several functional contexts, including funerary and varied everyday features (for example, storage silos, ovens, bonfires), resulting from a homogeneous and relatively short-lasting prehistoric cultural phase. It also presents a series of remarkable depositional events, such as the rare occurrence of deposits arranged with some formality, and the intentional incorporation of anachronistic items. In order to gain a more accurate and reliable insight into the range of depositional histories operating in this case study we have focussed our attention on its ceramic assemblage. Thus, variability in the 
preservation and fragmentation condition of potsherds has been thoroughly assessed. A refitting experiment has also been performed aimed at tracking their belonging to the same vessels. These variables have been widely tested in other studies (for example, Hill, 1995; Sørensen, 1996; Garrow et al., 2005; Brudenell \& Cooper, 2008; Lamdin-Whymark, 2008; Edwards, 2009) and constitute informative and effective ways to address overarching taphonomic questions such as the trajectories undergone by sherds after the breakage of pots, the provenance and temporalities of contents per feature, or the degree of intentionality involved in such depositions. Unfortunately, however, the available collection lacks some basic conditions to fully support such a survey. Its main drawback is the definitive loss of the bulk of ceramics following their depositing in the Museum of Burgos in 1996, because these mundane archaeological materials were not stored at the institution. Only the decorated or selected materials, representing 22.4 per cent of the ceramic assemblage originally recovered, have survived. Keeping in mind this bias, we have considered the remaining ceramic sample worthy of further characterization. Certainly it cannot offer a desirable overall and precise picture of the depositional dynamics at this site (cf. Hill, 1995; Garrow et al., 2005; Brudenell \& Cooper, 2008; Edwards, 2009), but at least a series of useful observations may be made to obtain a complementary dataset.

An examination of a set of depositional contexts-fourteen out of twenty-eight prehistoric cut features (Figure 2) and sixty-one per cent of the stratigraphic units (SU) - has been carried out based on their variety and representativeness. Not all the ceramic material retrieved and recorded in 1996 has been studied by the authors, due to the above-mentioned subsequent loss of part of it. Detailed measurements (length, width, thickness, and weight) of 312 ceramic sherds-representing fifteen per cent of the total ceramic assemblage unearthed in 1996have been recorded (Table 1 ). This dataset of examined items represents the whole ceramic assemblage surviving in the Museum of Burgos and includes all the decorated and feature sherds (bases, rims, carinations, etc.) originally found. Table 1 includes the percentage of the total fragments originally found per feature. The abrasion and size of the remaining ceramic collections from the selected features have been assessed, and their percentage representativeness per feature has been scored in Figure 8. The size of sherds has been recorded as an area measure: length multiplied by width expressed in centimetre square to create one measure instead of two (length and width). These variables have been explored through descriptive statistics and some inferential tests. Finally, a refitting experiment employing the existing diminished sample has been implemented in order to test intra-feature and possible cross-feature matching sherds (Garrow et al., 2005: 149-51; Chapman \& Gaydarska, 2007). To assess the state of preservation, a scheme with five different types or degrees of pre-pit or pre-depositional abrasion has been developed (Table 2), partly following the recording system employed by Edwards (2009: 147-59) whose scoring method is in turn based on Sørensen (1996: 66-67). The following attributes have been taken into account (Table 2): (a) sharpness of the breaks (sharp or blunt); (b) texture of the cores (rough or smooth) related to temper grains; and (c) condition of surfaces (unpatinated or dull). Different ceramic fabrics may affect the preservation condition of sherds, and therefore it is important to note that Bronze Age and Beaker ceramics contain varied inclusions but, generally speaking, are well fired and 


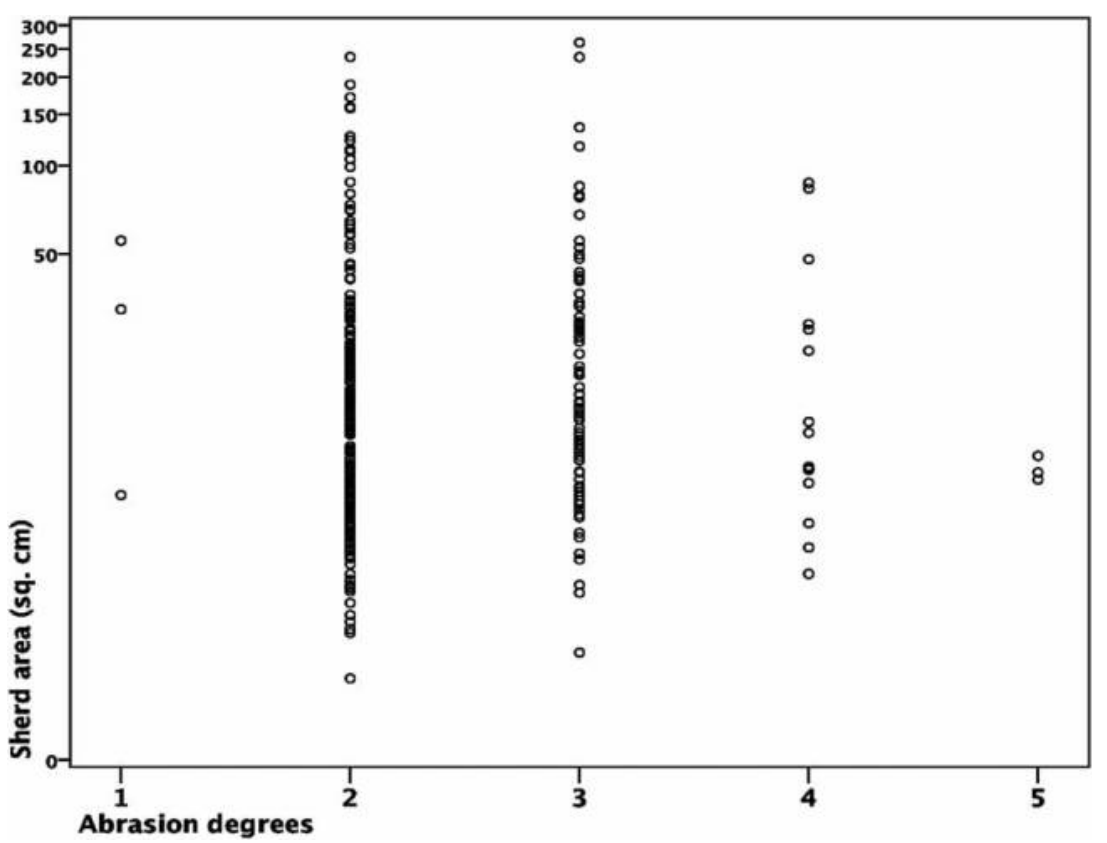

Figure 8. Graph showing the area and abrasion levels of the studied potsherds from El Cerro.

durable items, whereas Early Neolithic fragmentation. The different sizes are ceramics are softer, especially when wet. found proportionally in all the features Bearing in mind the foregoing precautions (Table 1). In order to highlight possible and restrictions of the studied ceramic sample, the remainder of this section presents our main observations.

The results of these analyses have clarified the above mentioned questions. In the whole assemblage, almost sixty-five per cent of the sherds are smaller than $25 \mathrm{~cm}^{2}$ differences among the ceramics, we have studied them separately. The Middle Bronze Age sherds (Figure 9) score a low degree of abrasion, as seventy-two per cent of them have been classified in the second degree of erosion (Table 2). Due to the homogeneity of the sample, size was not (Figure 8), indicating a high degree of included in the analysis of the abrasion.

Table 2. Degrees of abrasion used to score the ceramic assemblage from El Cerro.

\begin{tabular}{|c|c|c|c|c|}
\hline Degree & Condition & Edges & Surfaces & Example \\
\hline 1 & No abrasion & $\begin{array}{l}\text { Very fresh breaks. Rough temper } \\
\text { grains. }\end{array}$ & Unpatinated surfaces. & Fig. 6 \\
\hline 2 & Low abrasion & $\begin{array}{l}\text { Almost fresh, but becoming blunt. } \\
\text { Unpatinated core. }\end{array}$ & Unpatinated surfaces. & Fig. $5 \mathrm{C} 2$ \\
\hline 3 & $\begin{array}{l}\text { Medium } \\
\text { abrasion }\end{array}$ & $\begin{array}{l}\text { Edges maintain sharpness but } \\
\text { edges and temper are worn. }\end{array}$ & One surface is patinated. & Fig. 5B1 \\
\hline 4 & High abrasion & Points and edges are worn blunt. & $\begin{array}{l}\text { One side is less abraded than the } \\
\text { other, but both are patinated. }\end{array}$ & Fig. 5B4 \\
\hline 5 & $\begin{array}{l}\text { Very high } \\
\text { abrasion }\end{array}$ & $\begin{array}{l}\text { Very rounded edges. The sherd is } \\
\text { heavily rolled. }\end{array}$ & $\begin{array}{l}\text { Both sides are eroded and have very } \\
\text { patinated surfaces. }\end{array}$ & Fig. 5B2 \\
\hline
\end{tabular}




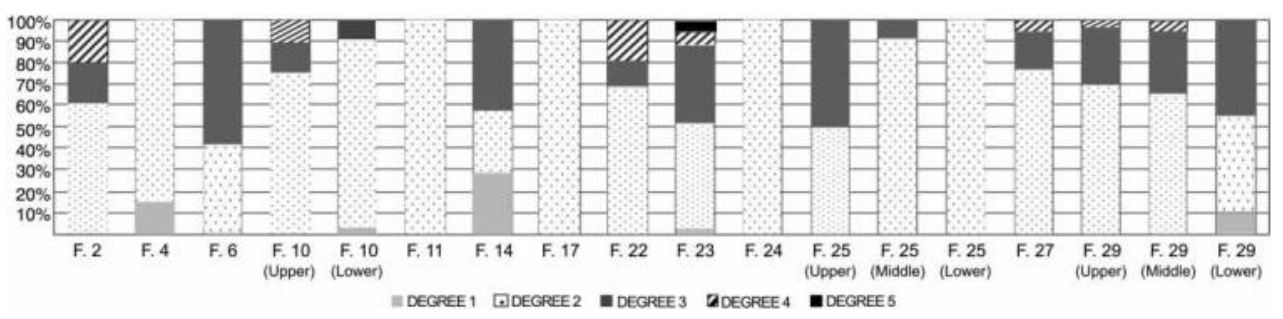

Figure 9. Cumulative percentage graphs with the abrasion levels of the studied potsherds.

However, counter-intuitively, there is neither a linear nor an ordinary relationship between abrasion and size of the sherds (Figure 8) (Pearson correlation = 0.096 and Kendall's B-Tau $=0.058 ; \mathrm{p}=$ 0.695); in other words, smaller size does not imply a poorer degree of preservation. There is a disconnection between sherd size and weathering timespan (abrasion level) as observed at the English Neolithic site of Thirlings (Edwards, 2009: 159). This means the shattering of ceramics is not directly related to their pre-pit context. Testing these variables according to depositional context has been very illuminating. The less worn and more fragmented sherds are predominant in a series of features such as F. 2, F. 4, F. 6, F. 11, F. 17, and F. 24 (Figure 9). Nonetheless, eighty-four per cent of the studied ceramic sample corresponds to a wider spectrum of variability, as in F. 10, F. 23, F. 25, F. 27, and F. 29 (Figure 9)-probably the by-product of more complex formation processes.

Size and abrasion of the Early Neolithic and Beaker sherds tend to be different from the Bronze Age ceramic fragments: the weathering condition and size of both sets of anachronistic items are weakly related, but negatively (Kendall's B-Tau = $-0.420 ; p=0.035)$. That is to say that the larger sherds are less abraded. The Neolithic pieces are bigger $\left(\right.$ mean $\left.=64.1 \mathrm{~cm}^{2}\right)$ and exhibit a better preservation condition than the average values for Bronze Age ceramics. Thus, seventy-five per cent of these older sherds were placed according to our classification in the third level of abrasion (Table 2). This is the case of the Neolithic fragments placed within SU 2901, the uppermost level in F. 29, which exhibit a 'freshly broken' aspect (Figures 3H and 5, B1) even though they are at least 2000 years older than the Bronze Age ceramics. Significantly, only two out of twenty Neolithic sherds (those inside pit-house F. 23) were so worn that it was difficult to distinguish their exterior decoration (Figure 5, B2 and B3). On the other hand, the three Beaker sherds are large (Figure 5, C1 and C2) or mediumsized (Figure 5, C3) and all of them exhibit fresh fractures. These data reinforce the initial impression that they could have been affected by pre-pit circumstances different to those suffered by most Bronze Age remains. In short, size and abrasion values for Neolithic and Beaker sherds do not match those expected. These anachronistic sherds seem to have been collected and treated with certain care, limiting their weathering or erosion.

The refitting of sherds (nearly three per cent of the 312 items) suggests that nearby cut features were filled within a short time-span, as they yielded several conjoining or possibly matching sherds. Thus, secure or physical cross-feature refits include Middle Bronze Age sherds in F. 25, F. 29, F. 24, and F. 27 (Figure 10). Non-adjoining Beaker sherds 


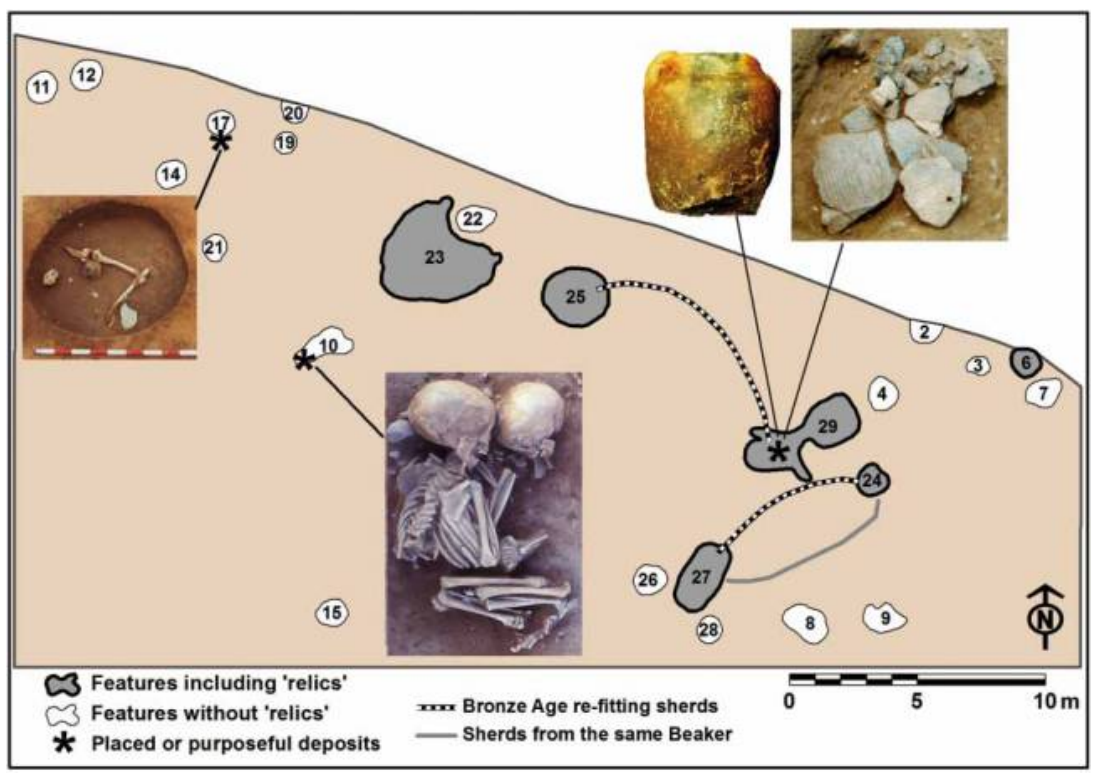

Figure 10. Different patterns among features: while some of them yielded refits, others contained purposeful deposits and relics.

from F. 24 and F. 27 are very likely from the same vessel and constitute a probable cross-feature link (Figure 5, C2 and C3, and Figure 10). In addition, several intrafeature physical refits have been identified within F. 29, between its intermediate (SU 2902) and basal (SU 2903) layers. However, it has not been possible to refit any whole vessel, not even the almost complete bowls from F. 29. Thus, we can suggest that these features were very likely backfilled in a short time-span-due to the occurrence of such refits and the limited and homogeneous degree of sherd erosion (Garrow et al., 2005).

\section{Discussion}

Our interest in the archaeological evidence from El Cerro was initially prompted by the rare occurrence of burial, settlement, 'structured', and everyday deposits all together in the same spot. In the last two decades, many Middle Bronze Age sites have been extensively excavated in the Iberian Meseta. Generally speaking, they consist of scatters of pits filled with everyday discarded material culture (secondary debris) and some unusual deposits, such as faunal or human remains. Although thousands of hectares have been studied by archaeologists, funerary evidence (Esparza et al., 2012a) and especially in situ domestic evidence (Blanco-González, 2011; Sánchez-Polo, 2011) seem to be quite unusual. The identification of purposefully arranged deposits has been more successful (Sánchez-Polo, 2011; Liesau, 2012). However, there is always the risk of isolating and decontextualizing this kind of evidence from the wider picture and to focus exclusively on one depositional type at the expense of others (Brudenell \& Cooper, 2008: 16; Garrow, 2012: 105). To sum up, the information recovered from the relatively limited area investigated at El Cerro (around $0.05 \mathrm{ha}$ ) is remarkable because, for the first time in the Iberian Meseta, the analysis of several 
elements shows the full spectrum of depositional practices of those prehistoric peoples: from the material results of outstanding exceptional gestures to the more unintended casual practices of routine refuse disposal (Brudenell \& Cooper, 2008; Garrow, 2012).

Some pieces of evidence stand out at first sight as highly conspicuous occurrences. The most unambiguous depositions are the three subadults in F. 10 and the leg of a cow in F. 17 (Figure 10). These deposits are close to the highest end of the theoretical continuum of formality and intentionality in depositional practices (Lamdin-Whymark, 2008: 175), and could be regarded as 'structured' or 'odd deposits' (for example, Brück, 1999b; Garrow, 2012). They might have involved the selective and explicitly arranged deposition of certain materials.

Moving downwards on this sliding scale, we find some apparently prearranged materials within some other features. The clearest case is the fill of hollow F. 29 with three different sediments containing remarkable archaeological materials. A succession of depositional episodes can be tracked through its stratigraphic sequence: first, it was filled with sediments (SU 2903) containing small quantities of moderately eroded ceramic sherds (Table 1 and Figure 9)-apparently mundane settlement waste quickly discarded in the pit. After that, we can distinguish a level (SU 2902) very rich in animal bones and ceramic debris, including several halves of individual bowls and large storage pots (Table 1), which might relate to a social gathering involving commensality. Finally, the last depositional episode (SU 2901) involved the apparent placement of a small jug (Figure 6) and the nearby placed ensemble of Early Neolithic grooved sherds (Figure 3H). This heap of decorated fragments from the same vessel definitely cannot be regarded as unnoticed and redeposited erratic residues. Importantly, even the more clearly intentional deposits such as those recognized within F. 10, F. 17, or F. 29 are embedded in sediments containing large numbers of casual items resulting from varied and complex depositional trajectories (that is, erratic, secondary or tertiary residues) (Figure 9).

On an even lower level of the theoretical continuum of formality in depositional dynamics, we might place the discovery of further anachronistic items. Thus, in the view of the pattern recognized in F. 29, the presence within F. 6 (some $10 \mathrm{~m}$ from F. 29) of three 'freshly broken' sherds from the same Neolithic vessel (Figure 5, B4) seems difficult to have come about by chance. Rather, we can assume a certain degree of awareness when they were concealed in this pit, yet the archaeological result is far less patterned. An analogous mechanism could be responsible for the filling of hut F. 23. As usually happens with Bronze Age living quarters in the Iberian Meseta, the sediment and contents of this sunken feature do not match the expected repertoire of an everyday domestic context. F. 23 was filled with a unique homogeneous grey deposit containing 209 sherds (Table 1), which cannot be confused with de facto refuse (LaMotta $\&$ Schiffer, 1999): none of the sherds refit or had been broken in situ and they exhibit intense erosion (Figure 9). These traits fit a depletion activity — sweeping and picking up the reusable items, followed by a single and rapid accretion process-dumping ashy sediment with occasional secondary residues. These gestures obliterated the original layout of the living or 'systemic' context (LaMotta \& Schiffer, 1999; Chapman \& Gaydarska, 2007: 71-75; Webley, 2007). It is very likely that the two heavily worn Neolithic sherds were thrown into the house during its closure (Figure 5, B2 and B3 and Figure 7A), 
perhaps as cherished tokens. And this might also have been the case with the Beaker sherds in pits F. 24 and F. 27 (Figure 7B). With regard to the microliths (Figure 7A), during the Middle Bronze Age the knapping of flint blades was restricted to particular utensils and the expedient production of flint and quartzite flakes was mainly for sickle elements (Blasco et al., 2007: 129-36; Rodríguez Marcos, 2007: 388-93). Bearing in mind the presence of other Early Neolithic materials within the nearby features, such microlithic items can be reasonably dated to this period, when they were more abundant. However, it is highly unlikely they were deliberately incorporated into pits F. 24, F. 25, and F. 27. Because of their tiny size (they are around $2 \mathrm{~cm}$ in length; Figure 5, A1-A4), they would have been hard to see and thus they might have entered those pits unwittingly as unnoticed residues.

The remaining features at $\mathrm{El}$ Cerrofilled with monotonous strata and homogeneous quantities of material-seem to have been filled in a much more routine, non-reflective, and less prescribed fashion, and their archaeological interpretation in terms of intentionality relies on an uncomfortable level of ambiguity. Their precise characterization is very difficult, as it has not been possible to meet Brudenell and Cooper's (2008: 33) requirement of examining all the contents of every individual feature in their entirety. However, a more in-depth assessment of the studied ceramic sample provides us with some noteworthy observations (Table 1). The widespread lack of bases (only seventeen examples, twelve of them of coarse ware) in contrast to the vessels Minimum Number of Individuals (Table 1) or the frequency of Neolithic handles, with three examples (Figure 5, B1), indicate the influence of certain biases in the selection of the ceramic assemblage, which did not form simply at random. On the other hand, the high level of fragmentation (Figure 9) and the impossibility of refitting even half of the vessels provide valuable information about the predepositional history of the ceramic debris and the prehistoric community's contextually specific ideas about their discard. Indeed, this is informative about intuitive or non-discursive actions of disposal systematically reproduced throughout varied Middle Bronze Age depositional contexts in the Iberian Meseta (Sánchez-Polo, 2011). In short, the filling of pits such as F. 2, F. 4, F. 11, F. 14, and F. 15 can be mainly envisaged in terms of casual and informal anthropogenic processes. Their sediments and contents were mainly cumulative and accidental material outcomes lasting imprecise periods of time until they eventually entered into the cut features (Figure 9), although they do inform us about past social practices and cultural values.

All in all, from the dataset presented above, an interpretive account can be offered. This hypothesis relies heavily on an uneven range of observations, some of which seem fairly secure, others more conjectural. Thus, regarding the burial evidence, a current working hypothesis on mortuary practices among Middle Bronze Age societies in the Iberian Meseta (Esparza et al., 2012b: 117-20) advocates that the normal funerary ritual (that is, the one applicable to most people) involved the exposure of corpses, leaving no archaeological traces. Only those exceptional cases of 'mauvaise mort' would have been excluded and relegated to pits. The three children found at El Cerro might be considered to lie among these deviant cases. There are good reasons for thinking so: (a) according to the radiocarbon dates, all of them died at the same time or within a short time-span, perhaps because of disease or an unfortunate accident 
(Esparza et al., 2012a: 281, 300, n. 25); (b) available aDNA evidence indicates that at least two of them were kin-related children; and (c) stratigraphic data point towards a simultaneous triple inhumation. Therefore, the conclusion that they were siblings who died and were interred concurrently seems quite sound. Moreover, we cannot overlook the fact that this rare multiple inhumation of children is spatially associated with the unusual remains of a hut and ubiquitous everyday features whose abandonment involved some premeditated actions and odd anachronistic items. In order to better understand these atypical archaeological outcomes, we can propose a specific cultural mindset among the community who lived there (Brück, 1999a; Sánchez-Polo, 2012). It is thus very tempting to link the life cycle of dwelling structure F. 23 to the biographies of its occupants (Brück, 1999b; Gerritsen, 1999; Sánchez-Polo, 2010: 180-82; Blanco-González, 2011: 398). There is, then, some scope for advocating the following hypothesis: the sudden and unexpected decease of three kin-related children in a small kin-based community would have represented a traumatic episode for the whole group of co-residents, most of whom might have been their relatives. This ill-fated accident might have been perceived as a perturbation in the natural order and a dangerous threat to the whole community. Coming to terms with this challenging turn of events would have required an $a d$ hoc cultural response, involving the assistance of ancestral or supernatural forces. This grieving process might have consisted of the abandonment of the settlement, the corpses and the household belongings related to them, which might have become polluted. Dealing with them probably required special participants and formalized steps with both pragmatic and magical consequences (Brück, 1999a), intended to re-establish the cosmological balance. Thus, some unique procedures (Figures 10 and 11) substituted both the normal funerary treatment and the habitual ways of abandoning a site.

The occurrence of numerous Early Neolithic and Beaker items in undisturbed Bronze Age contexts at El Cerro might be more satisfactorily understood, in the light of this hypothesis, as powerful participants in the divestment process. It is very unlikely that settlers at El Cerro in the second millennium BC acknowledged the actual historicity of such remains, but they might easily have recognized their otherness or alien character (Bradley, 2002; Hingley, 2009). The bulk of these sherds exhibit fresh edges and surfaces, proof of a certain careful post-breakage treatment (Figure 5, $\mathrm{B}$ and $\mathrm{C}$ ). Three of them even feature post-firing holes (Figure 5, B1) indicating their manipulation and probable repair during the Bronze Age, a widespread practice in this period. Therefore, they might have become 'curated' valuables, redolent of links with a mythical or genealogical past (Hingley, 2009)—relics (Woodward, 2002) or heirlooms inherited over a number of generations (Lillios, 1999: 239-44). Their retrieval is not problematic: El Cerro is located in the sedimentary lowlands near the Duero River (Figure 1), a region densely reoccupied by agrarian groups for millennia. Since Bronze Age people performed iterative pit-digging in the same places, the removal of older deposits and the encountering of such items was a highly likely occurrence (cf. Chapman \& Gaydarska, 2007: 174). Neolithic and Beaker sherds in Middle Bronze Age contexts with early Cogotas I ware have been documented elsewhere, as shown by a Beaker fragment from Peñalosa, an Argarian settlement in southern Iberia (Contreras \& Alarcón, 2012: 173, fig. 5). Furthermore, items related to ancestors were widely handled 


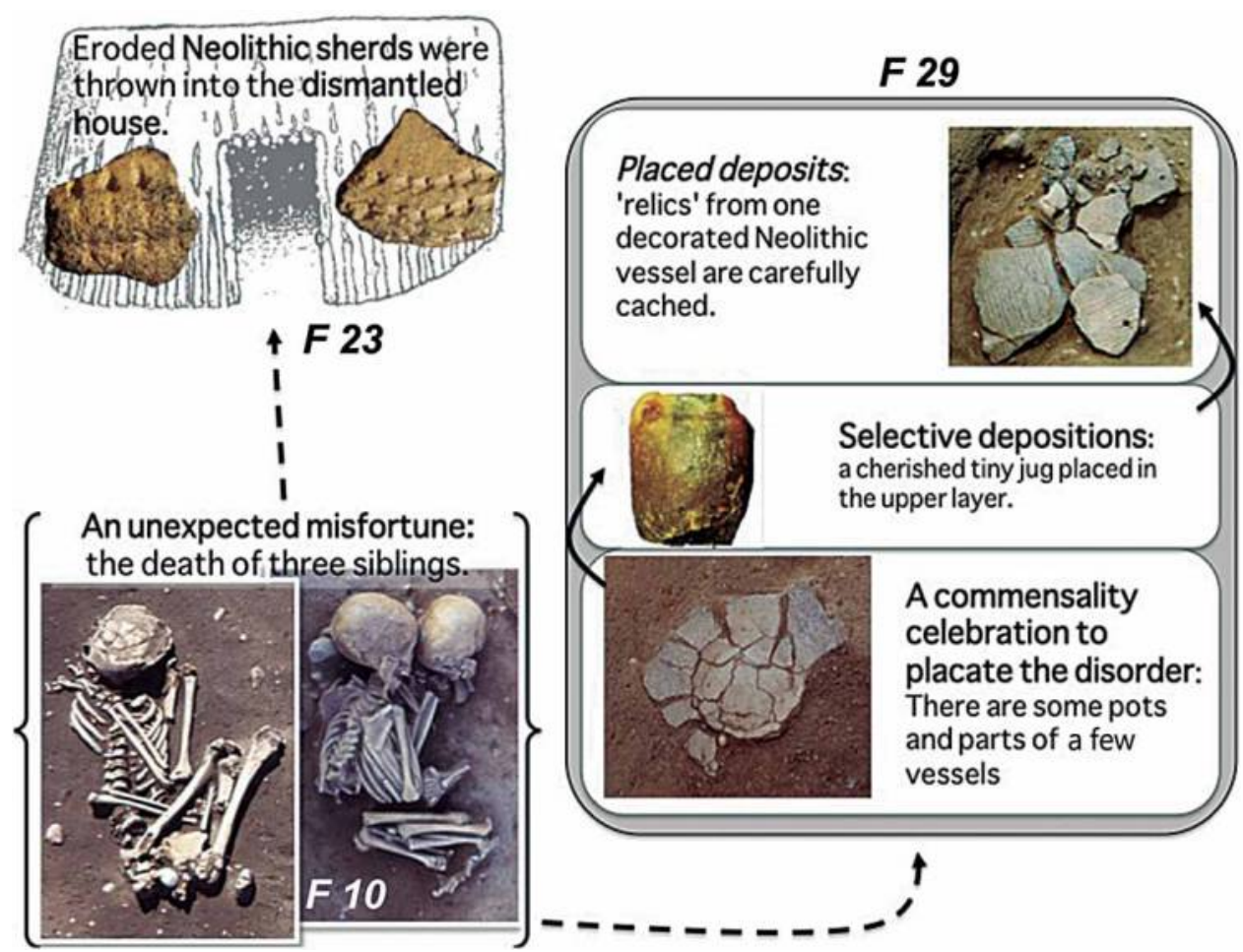

Figure 11. Diagram outlining the relationships between the different acts of deposition suggested for El Cerro.

Hut image after Jimeno \& Fernández (1991: 20, fig. 10).

and deployed by those communities. Thus, ancient dismembered human remains were sometimes introduced in Middle Bronze Age burials as a means of establishing real or fictional ancestry (Esparza et al., 2012a: 309-10). The circulation of all these relics might have been reenacted on a daily basis, through their exhibition aimed at maintaining the social reproduction of the households (Esparza et al., 2012a: 312). In short, the invocation of such supernatural entities in critical communal episodes is quite suggestive, and the divestment rituals at El Cerro site might have constituted a very appropriate course of action.

Continuing in this vein, a speculative sequence of actions relating certain features scattered across the area excavated in 1996 may be proposed (Figure 11). Their temporal succession is far from clear. As it has been noted (Garrow et al., 2005), neither the stylistic similarity of the ceramics nor the physical proximity of the pits provide a sufficiently accurate chronology for claiming their close concealment simultaneously. Neither is it possible to be certain the burial episode took place in the final stages of the site's occupation. However, at least the refitting of Bronze Age sherds between features F. 25 and F. 29 and between F. 24 and F. 27 (Figure 10) links their filling. Thus, a tragic episode might have been commemorated through a feast, involving the use of several bowls, some of them eventually discarded in ditch F. 29. The cow's leg in pit F. 17 might be associated with this ceremony, but it might equally have been an earlier propitiatory deposit or a 
foundation offering (Liesau, 2012). The management of burnt residues and ashy sediments from bonfires in F. 23, F. 25, and F. 27 also recalls some depositional patterns documented at La Requejada (Valladolid)-another triple burial containing members of a family (Esparza et al., 2012a: 309). Other clearly deliberate depositions might be associated with this sequence of events. Thus, a tiny jug (Figure 6), perhaps made and/or used by the children buried in F. 10, and especially the cache of large Early Neolithic sherds (Figure 11), were placed in the upper layer of F. 29. The closure of hut F. 23 also involved a series of formalized actions: once dismantled and covered by a homogeneous and clean layer, two eroded but hardly unnoticed Neolithic sherds might have been thrown into it (Figure 11), as part of the gestures performed to abandon the domestic quarter and to restore the cosmological balance broken by the siblings' deaths.

\section{Conclusions}

The main goal of this paper has been to accurately characterize the intriguing archaeological features documented at the Bronze Age site of El Cerro. Following recent successful attempts to characterize the formation processes through the study of ceramics (for example, Garrow et al., 2005; Brudenell \& Cooper, 2008; Lamdin-Whymark, 2008; Edwards, 2009), our self-critical and cautious appraisal of the variability of this ceramic assemblage has tried to understand every observation in connection with the overall depositional patterns at the site. It is worth noting that we have found an unexpectedly wide range of depositional dynamics by focusing on the ceramic assemblage. Thus, this site yielded twenty-eight adjacent archaeological features, which are the material by-products of contrasting formative histories. Importantly, even the more clear-cut 'structured' or placed deposits are made up of materials and sediments with heterogeneous chronologies and accumulative trajectories that are not always easily distinguishable. As a consequence, the archaeological recognition of the intentionality of depositional practices still largely depends on the premises and criteria used in their study. The importance of the accumulation of unintended effects should not be ignored, even in the case of the most conspicuous and apparently unambiguous assemblages.

Secondly, this paper has posited a speculative sequence of actions that might have led to the uncommon domestic and funerary outcomes discovered at the site of El Cerro. An all-too-easy, misleading account could have been obtained from this dataset, linking the dwelling structure, the pits and the burial deposition in a supposedly synchronic and frozen picture of past activities. This appraisal would have overlooked important evidence of prescribed and intentional forms of discard and abandonment (LaMotta \& Schiffer, 1999; Webley, 2007). The examined evidence allows us to conclude that this site does not reflect a faithful image of everyday life and death in Middle Bronze Age central Iberia. In our hypothetical reading, residential and productive tasks preceded the burial, and they were performed at different times. Moreover, both spheres (domestic and funerary) might have been incompatible: the death and subsequent treatment of the bodies might have meant the end point for the occupation of this place. Thus, from our perspective, the lifecycle of the settlement and the biography of its occupants would have been tightly intertwined (Brück, 1999b). A range of substances, including human corpses, animal parts, contemporary everyday 
debris, and otherworldly items or ancestral relics, might have been mobilized and eventually deposited in order to placate the disorder triggered by the misfortunate loss of three children in a family. Although we have suggested the relationship between several features because they shared refitted sherds or contained such valuable tokens (Figures 10 and 11), it has not been possible to date them precisely enough to place these episodes in an undisputable sequence.

Finally, even if the three children buried at Cerro were not actual siblings and their death did not lead to the abandonment of the site or its curious deposits, this case study is still a valuable one. This paper has opened up fresh perspectives to reappraise later prehistoric pit sites in the Iberian tablelands. The approach presented here, widely tested and discussed in the British archaeological milieu, might be envisaged as a ground-breaking contribution to Iberian prehistory. In fact, it is not possible to assess the representativeness of El Cerro inasmuch as there is no available comparison in Iberia, because no other contemporary sites have yet been tested by focusing on such issues. Prehistoric pit sites will soon benefit from similar methods of study, directed to gain information on the formation processes responsible for their archaeological appearance.

\section{ACKNowledgements}

This work was carried out within the research project 'New finds and new perspectives on the study of the Cogotas I culture human remains' (HAR 2009-10105) funded by the Spanish Ministry of Science and Innovation. Prof. Ángel Esparza (University of Salamanca) shared with us the preliminary results from aDNA analyses and kindly allowed us to use the three unpublished radiocarbon dates from $\mathrm{El}$ Cerro. We are very grateful to Ángel Palomino (Aratikos S.L.) for providing us with documentation and photos of his excavation at El Cerro in 1996. Dr Manuel Rojo (University of Valladolid) helped us with the identification of the Neolithic items. The staff at the Museum of Burgos were very kind during the study of the materials by A. S.-P. when she was preparing this case study as a presentation for the 17th Annual Meeting of the European Association of Archaeologists, held in Oslo in 2011. An earlier draft of this paper was improved by the critical comments offered by Dr Joanna Brück (Bristol University), Dr Robin Skeates (Durham University) and four anonymous reviewers. All opinions and possible misunderstandings remain ours.

\section{REFERENCES}

Abarquero, F.J., Blanco-González, A., Esparza, A. \& Rodríguez Marcos, J.A. 2013. The Central Iberian Meseta at the Time of the Thera Eruption: An Overview. In: H. Meller, F. Bertemes, H.-R. Bork \& R. Risch, eds. $1600-$ Kultureller Umbruch im Schatten des Thera-Ausbrucbs? Halle: Tagungen des Landesmuseums für Vorgeschichte Halle 9, pp. 315-326.

Blanco-González, A. 2011. From Huts to 'the House': The Shift in Perceiving Home Between the Bronze Age and the Early Iron Age in Central Iberia (Spain). Oxford Journal of Archaeology, 30(4):393-410.

Blasco, M.C., Blanco, J.F., Liesau, C., Carrión, E., García, J., Baena, J., Quero, S. \& Rodríguez, M.J. 2007. El Bronce Medio y Final en la región de Madrid. El poblado de la Fábrica de Ladrillos (Getafe, Madrid). Madrid: Ayuntamiento de Madrid.

Bradley, R. 2002. The Past in Prehistoric Societies. London: Routledge.

Brück, J. 1999a. Ritual and Rationality: Some Problems of Interpretation in European 
Archaeology. European Journal of Occupation: An Earlier Neolithic Site at Archaeology, 2(3):313-44. Kilverstone, Thetford, Norfolk. Proceedings

Brück, J. 1999b. Houses, Lifecycles and Deposition on Middle Bronze Age Settlements in Southern England. Proceedings of the Prehistoric Society, 65:145-66.

of the Prebistoric Society, 71:139-57.

-Gerritsen, F. 1999. To Build and to Abandon. The Cultural Biography of Late Prehistoric Houses and Farmsteads in the Southern Netherlands. Archaeological Dialogues, 6(2):78-97.

-Brudenell, M. \& Cooper, A. 2008. Post-Middenism: Depositional Histories on Later Bronze Age Settlements at Broom, Bedfordshire. Oxford Journal of Archaeology, 27(1):15-36.

Chapman, J. \& Gaydarska, B. 2007. Parts and Wholes. Fragmentation in Prehistoric Context. Oxford: Oxbow.

Contreras, F. \& Alarcón, E. 2012. La cultura de Cogotas I y las comunidades argáricas del Alto Guadalquivir: una perspectiva actual. In: J.A. Rodríguez Marcos \& J. Fernández Manzano, eds. Cogotas I. Una cultura de la Edad del Bronce en la Peninsula Ibérica. Valladolid: Universidad de Valladolid, pp. 165-85.

Edwards, B. 2009. Pits and the Architecture of Deposition. Narratives of Social Practice in the Neolithic of North-East England. PhD dissertation, University of Durham.

Esparza, A., Velasco, J. \& Delibes, G. 2012a. HUM 2005-00139: Planteamiento y primeros resultados de un proyecto de investigación sobre la muerte en Cogotas I. In: J.A. Rodríguez Marcos \& J. Fernández Manzano, eds. Cogotas I. Una cultura de la Edad del Bronce en la Peninsula Ibérica. Valladolid: Universidad de Valladolid, pp. 259-320.

Esparza, A., Velasco, J. \& Delibes, G. 2012b. Exposición de cadáveres en el yacimiento de Tordillos (Aldeaseca de la Frontera, Salamanca). Perspectiva bioarqueológica y posibles implicaciones para el estudio del ritual funerario de Cogotas I. Zephyrus, 59 (1):95-128.

Estremera, S. 2003. Primeros agricultores y ganaderos en la Meseta Norte. El neolitico de la cueva de La Vaquera (Torreiglesias, Segovia). Valladolid: Junta de Castilla y León.

- Garrow, D. 2012. Odd Deposits and Average Practice. A Critical History of the Concept of Structured Deposition. Archaeological Dialogues, 19(2):85-115.

- Garrow, D., Beadsmoore, E. \& Knight, M. 2005. Pit Clusters and the Temporality of

Hill, J.D. 1995. Ritual and Rubbish in the Iron Age of Wessex: A Study on the Formation of a Specific Archaeological Record. Oxford: British Archaeological Reports.

Hingley, R. 2009. Esoteric Knowledge? Ancient Bronze Artefacts from Iron Age Contexts. Proceedings of the Prehistoric Society, 75:143-65.

Jimeno, A. \& Fernández, J.J. 1991. Los Tolmos de Caracena (Soria) (Campañas 1981 y 1982). Aportación al Bronce Medio de la Meseta. Madrid: Ministerio de Cultura.

Lamdin-Whymark, H. 2008. The Residue of Ritualised Action: Neolithic Deposition Practices in the Middle Thames Valley. Oxford: British Archaeological Reports.

LaMotta, V. \& Schiffer, M.B. 1999. Formation Processes of House Floor Assemblages. In: P. Allison, ed. The Archaeology of Household Activities. London: Routledge, pp. 19-29.

Liesau, C. 2012. Depósitos con ofrendas de animales en yacimientos Cogotas I: antecedentes y características. In: J. A. Rodríguez Marcos \& J. Fernández Manzano, eds. Cogotas I. Una cultura de la Edad del Bronce en la Península Ibérica. Valladolid: Universidad de Valladolid, pp. 219-57.

Lillios, K.T. 1999. Objects of Memory: The Ethnography and Archaeology of Heirlooms. Journal of Archaeological Method and Theory, 6(3):235-62.

Negredo, M. \& Palomino, A.L. 1997. Excavación arqueológica en el yacimiento de 'El Cerro', La Horra (Burgos). Unpublished report for the Cultural Heritage Department of the Autonomous Government of Castile and Leon.

Palomino, A.L., Negredo, M.J. \& Abarquero, F.J. 1999. Cabañas, basureros, silos y tumbas en el yacimiento de El Cerro, La Horra (Burgos): a vueltas sobre el significado de un campo de hoyos en la Edad del Bronce de la Meseta. Numantia, 7:21-41.

Pollard, J. 2002. The Nature of Archaeological Deposits and Finds Assemblages. In: 
A. Woodward \& J.D. Hill, eds. Prehistoric Britain. The Ceramic Basis. Oxford: Oxbow, pp. 22-33.

Reimer, P.J., Baillie, M.G.L., Bard, E., Bayliss, A., Beck, J.W., Blackwell, P.G., Bronk Ramsey, C., Buck, C.E., Burr, G. S., Edwards, R.L., Friedrich, M., Grootes, P.M., Guilderson, T.P., Hajdas, I., Heaton, T.J., Hogg, A.G., Hughen, K.A., Kaiser, F.K., Kromer, B., McCormac, G., Manning, S., Reimer, R.W., Richards, D. A., Southon, J.R., Talamo, S., Turney, C. S.M., van der Plicht, J. \& Weyhenmeyer, C.E. 2009. INTCAL09 and MARINE09 Radiocarbon Calibration Curves, 0-50,000 Years Cal BP. Radiocarbon, 51(4):111150.

Rodríguez Marcos, J.A. 2007. Estudio secuencial de la Edad del Bronce en la Ribera del Duero (provincia de Valladolid). Valladolid: Junta de Castilla y León.

Sánchez-Polo, A. 2010. La muerte en la arqueología. Visiones cruzadas/posiciones encontradas [online]. El Futuro del Pasado, 1:173-87 [accessed 10 January 2013]. Available at: <http://www.elfuturodelpa sado.com/elfuturodelpasado/eFdP_1.html>

Sánchez-Polo, A. 2011. Los 'campos de hoyos' del grupo Cogotas I y prácticas de ritualización: aportación al estudio de la Edad del Bronce del interior peninsular. Unpublished MA dissertation, University of Salamanca.

Sánchez-Polo, A. 2012. Depósitos de cerámicas, molinos y elementos de hoz. Una propuesta de la Edad del Bronce del interior peninsular desde la Arqueología Posprocesual. Arkeogazte, 2:73-93.

Sørensen, M.L.S. 1996. Pottery Evidence for Formation Process in the Late Bronze Age Deposits. In: S. Needham \& T. Spence, eds. Refuse and Disposal at Area 16 East, Runnymede, Volume 2. London: British Museum Press, pp. 61-73.

-Webley, L. 2007. Using and Abandoning Roundhouses: A Reinterpretation of the Evidence from Late Bronze Age-Early
Iron Age Southern England. Oxford Journal of Archaeology, 26(2):127-44.

-Woodward, A. 2002. Beads and Beakers: Heirlooms and Relics in the British Early Bronze Age. Antiquity, 76:1040-7.

\section{BiographicAl Notes}

Alejandra Sánchez-Polo obtained her MA at the University of Salamanca (Spain) in 2011. She is currently a $\mathrm{PhD}$ candidate at the same institution working on the issue of a broader understanding of ritual behaviour in the Spanish Bronze Age thanks to a Scholarship funded by the Autonomous Government of Castile and Leon (Formación de Personal Investigador Programme).

Address: Departamento de Prehistoria, $\mathrm{Ha}$ Antigua y Arqueología, Universidad de Salamanca, Salamanca. C/ Cervantes s/n. CP 37002. Spain. [email: asanpol@usal.es].

Antonio Blanco-González was awarded a $\mathrm{PhD}$ by the University of Salamanca in 2009. He holds a Marie Curie post-doctoral research fellowship at Durham University, UK. His interests include landscape archaeology, the cultural biography of material culture and the depositional practices of later prehistoric European societies.

Address: Department of Archaeology, Durham University, South Road, Durham. DH1 3LE. UK. [email: ablanco glez@gmail.com]. 


\section{Décès, reliques et délaissement de maisons: des modèles d'abandon planifié en Ibérie centrale pendant l'Âge du Bronze moyen}

Le présent article traite des processus de formation d'un lieu unique de l'Âge du Bronze de la Meseta ibérique. Le site de El Cerro (Burgos, Espagne) présente toute une série de caractéristiques complexes: inbumation simultanée de trois enfants à côté d'un quartier d'babitations et fosses adjacentes, dont quelques-unes avaient apparement été remplies avec cérémonie et contenaient des éléments anachroniques, notamment des objets provenant du Néolitbique et de la Culture des Gobelets campaniformes, ainsi que plusieurs dépôts, comme par exemple une jambe de vache. On réalisa une évaluation critique de l'ensemble contextuel de données, une opération de réaménagement et une évaluation de l'abrasion et de la taille d'un échantillon sélectif de céramique. Les particularités archéologiques du site sont interprétées comme réponse culturelle relevant d'un contexte spécifique pour gérer un épisode grave et traumatisant: la mort d'une jeune fratrie, qui entraina l'abandon du lieu en suivant des pratiques prescrites. Plusieurs dépôts laissent reconnaître un certain degré d'intentionalité, tandis que d'autres semblent plutôt être des accumulations involontaires. Translation by Isabelle Gerges.

Mots-clés: Âge du Bronze moyen, Meseta ibérique (Espagne), processus de formation culturels, inhumation déviante, abrasion et fragmentation de la céramique, dépôt intentionnel

\section{Tod, Relikte und das Ende von Hütten: Muster geplanten Abbruches im mittelbronzezeitlichen Zentraliberien}

Dieser Beitrag behandelt die Formationsprozesse in einer bislang einzigartigen bronzezeitlichen Siedlung in der iberischen Meseta. Der Fundplatz El Cerro (Provinz Burgos, Spanien) weist eine Reihe von herausragenden Merkmalen auf, darunter die gleichzeitige Bestattung dreier Kinder neben einem Wohnviertel und angrenzenden Gruben, von deren Inventaren sich einige auffallig wiederbolten und altertümliche Elemente des Neolithikums und der Becherkulturen sowie verschiedene besondere Deponierungen, darunter das Bein eines Rindes, enthielten. Eine kritische Beurteilung der kontextuellen Daten, eine Nachbesserungsmaßnahme sowie eine Beurteilung des Abriebs und der Größe einer bestimmten Keramikauswahl wurden durchgeführt. Die archäologischen Besonderheiten des Fundplatzes werden als kontextuell spezifische kulturelle Reaktion erklärt, mit einer schmerzlichen und traumatischen Episode-dem Tod dreier Geschwister im Kindesalter-umzugehen, was die Aufgabe der Siedlung im Zuge vorgeschriebener Praktiken nach sich zog. Einige Niederlegungen weisen ein erkennbares Maß an Intentionalität auf, während andere als unbeabsichtigte Akkumulationen gewertet werden. Translation by Heiner Schwarzberg.

Stichworte: Mittelbronzezeit, Iberische Meseta (Spanien), kulturelle Formationsprozesse, Sonderbestattung, Keramikabrieb und -fragmentation, intentionelle Deponierung 